\title{
Pengaruh Informasi Akuntansi dan Permintaan Investor terhadap Underpricing
}

\author{
Made Aida Pradnyadevi ${ }^{1}$ \\ Fakultas Ekonomi dan Bisnis \\ Universitas Udayana, Indonesia \\ Email: aidapradnyadevi@gmail.com
}

\author{
I Made Sadha Suardikha² \\ Fakultas Ekonomi dan Bisnis \\ Universitas Udayana, Indonesia
}

\begin{abstract}
ABSTRAK
Underpricing adalah fenomena yang sering kali terjadi dari kegiatan IPO di BEI. Underpricing adalah perbedaan harga saham yang terjadi dipasar perdana dan pasar sekunder, dimana harga penawaran lebih rendah dari pada harga penutupan hari pertama perdagangan. Tujuan peneilitian ini yaitu untuk mengetahuin pengaruh informasi akuntansi dan permintaan investor terhadap underpricing. Penelitian ini dilakukan pada perusahaan yang IPO di BEI pada tahun 2016-2018. Pengumpulan data. diperoleh , dari pengumpulan prospektus, serta laporan .keuangan perusahaan. Jumlah sampel sebanyak 81 perusahaan dengan menggunakan metode purposive sampling. Teknik analisis yang digunakan yaitu analisis regresi linier berganda. Penelitian ini membuktikan bahwa profitabilitas dan ukuran perusahaan berpengaruh negatif terhadap underpricing, sedangkan financial leverage dan permintaan investor tidak; berpengaruh;:terhadap underpricing.
\end{abstract}

Kata Kunci: Underpricing; Profitabilitas; Financial Leverage; Permintaan Investor.

\section{The Effect of Accounting Information and Investor Demand on Underpricing}

\section{ABSTRACT}

Underpricing is a phenomenon that often occurs from IPO activities on the IDX. Underpricing is the difference in stock prices that occur in the primary .market' and secondary' market, where the bid price is lower than the closing price of the first trading day. The purpose of this research is to find out the effect of accounting information and investor demand on underpricing.This research was conducted'.at companies whose IPO on .the' Stock. Exchange in 2016-2018. Data collection was obtained from the collection of prospectuses and company financial statements. The total sample of 81 companies using a purposive sampling method. The analysis technique used is multiple linear regression analysis. This study proves that profitability and firm size negatively affect underpricing, while financial leverage and investor demand have no effect on underpricing.

Keywords: Underpricing; Profitability; Company Size; Investor Demand.

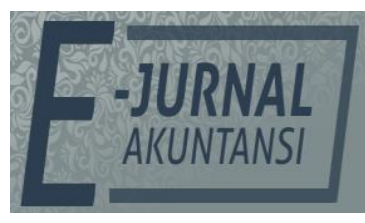

E-JA

e-Jurnal Akuntansi e-ISSN 2302-8556

Vol. 30 No. 3

Denpasar, Maret 2020

Hal. 746-759

Artikel Masuk:

23 Desember 2019

Tanggal Diterima: 9 Januari 2020 


\section{PENDAHULUAN}

Kebutuhan dana suatu perusahaan akan terus meningkat seiring dengan perkembangan dan pertumbuhan perusahaan. Perusahaan yang mebutuhkan dana tentunya tidak hanya mengandalkan pihak internal perusahaan saja, maka dari itu dengan adanya keterbatasan tersebut sebuah perusahaan melakukan go public dengan cara menjual sahamnya kepada publik. Initial Public Offering (IPO) merupakan penawaran saham untuk pertamakalinya kepada masyarakat luas (Hartono, 2017). Fenomena menarik yang sering terjadi dari kegiatan IPO adalah terjadinya fenomena harga rendah (underpricing). Kim et al., (1995) mengatakan bahwa terjadinya underpricing disebabkan karena penentuan harga saham pada saat IPO lebih rendah dibandingkan dengan harga saham di pasar sekunder hari pertama. Fenomena underpricing tersebut tentunya akan merugikan perusahaan karena tidak maksimumnya dana yang diperoleh dari publik (Wiyani, 2016).

Fenomena underpricing dapat disebabkan oleh informasi asimetri di pasar perdana. Asimetri informasi dapat dialami oleh investor ketika investor yang satu dengan yang lainnya tidak memiliki informasi yang sama, kemungkinan satu atau lebih investor memiliki informasi yang lebih mendalam tentang suatu perusahaan dibandingkan dengan investor yang lainnya yang tidak memiliki informasi yang mendalam melainkan hanya memperoleh informasi dari publik saja (Brown \& Hillegeist, 2007). Asimetri informasi dianggap dapat menyusahkan investor untuk menilai kualitas perusahaan yang melakukan penawaran perdana dengan objektif (Utamaningsih et al., 2013).

Asimetri informasi dapat terjadi antar emiten, penjamin emisi maupun antar investor. Sehingga untuk mengurangi adanya asimetri informasi maka dapat dilakukan penerbitan prospektus oleh perusahaan. Prospektus berisi rincian tentang informasi serta fakta material tentang penawaran umum emiten baik berupa informasi keuangan maupun non keuangan. Informasi yang terdapat pada prospektus membantu investor untuk membuat keputusan yang rasional mengenai risiko nilai saham sesungguhnya yang ditawarkan emiten (Wiyani, 2016). Prospektus perusahaan adalah sumber informasi relevan yang tentunya digunakan untuk menilai perusahaan yang akan go public dan untuk mengurangi adanya kesenjangan informasi (Mayasari et al., 2018). Informasi dalam prospektus terdiri dari dua, yaitu informasi akuntansi dan non akuntansi. Penelitian ini menggunakan informasi akuntansi karena saat investor akan membeli saham yang dilihat terlebih dahulu pada sebuah perusahaan adalah kondisi keuangannya atau informasi akuntansinya.

Penelitian tentang informasi akuntansi yang mempengaruhi underpricing sudah banyak dilakukan. Informasi akuntansi yang umum diteliti adalah profitabilitas, Financial Leverage dan ukuran perusahaan. Penelitian tentang profitabilitas sudah dilakukan oleh Permadi \& Yasa (2017); Ramadana (2018) hasil penelitian menunjukkan bahwa profitabilitas yang diproksikan dengan return on asset berpengaruh negatif terhadap undepricing, sedangkan penelitian Widhiastina \& Prihatni (2016) menemukan bahwa return on asset berpengaruh positif terhadap underpricing. Adhiati (2015); Yanti \& Yasa (2016) menemukan return on asset tidak berpengaruh pada underpricing. Penelitian tentang Financial Leverage sudah dilakukan oleh Adhiati (2015); Widhiastina \& Prihatni (2016) menemukan bahwa debt to equity ratio berpengaruh negatif terhadap underpricing, 
sedangkan penelitian Maulidya \& Lautania (2016); Permadi \& Yasa (2017); Ramadana (2018) menemukan bahwa debt to equity ratio berpengaruh positif pada underprcing. Yasa \& Hartono (2003); Assari et al., (2014); Lestari \& Sulasmiyati (2017) menemukan bahwa debt to equity ratio tidak berpengaruh. terhadap underpricing. Penelitian tentang ukuran perusahaan sudah dilakukan oleh Maulidya \& Lautania (2016); Permadi \& Yasa (2017); Mayasari et al., (2018); Ramadana (2018) penelitian ini menemukan bahwa ukuran perusahaan berpengaruh negatif terhadap underpricing. penelitian Yasa \& Hartono (2003); Adhiati (2015); Yanti \& Yasa (2016) menemukan bahwa ukuran perusahaan tidak berpengaruh terhadap underpricing.

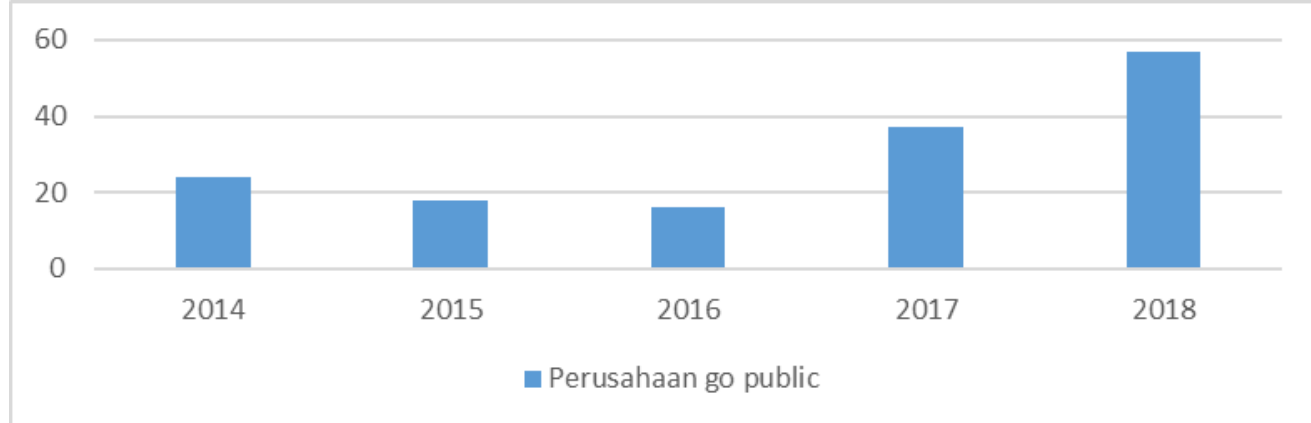

Sumber: Data Penelitian, 2019

Gambar 1. Perusahaan Go Public 2014-2018

Berdasarkan Gambar 1. perkembangan perusahaan yang go public di Bursa Efek Indonesia dari tahun 2014-2016 terjadi penurunan akan tetapi dari tahun 2016-2018 terjadi peningkatan yang sangat tajam. Perusahaan yang go public ternyata banyak yang mengalami underpricing yang salah satu kemungkinannya disebabkan oleh permintaan saham yang melebihi penawaran (oversubscribed). Dilansir dari pemberitaan online tirto.id pada tanggal 17 juni 2019, geliat saham Bali United di bursa efek mengalami permintaan saham yang melonjak tinggi. Sebelumnya saham Bali United ini awalnya sempat underestimate, akan tetapi saat setelah di buka penawaran publik, responnya bagus sekali. Saham Bali United di bursa ini cukup diminati investor, hingga mengalami kelebihan permintaan. Pemberitaan online finance.detik.com pada tanggal 5 april 2019, PT Capri Nusa Satu Properti Tbk (CPRI) melantai di pasar modal, dalam masa penawaran saham CPRI juga mengalami kelebihan permintaan. Dilihat dari pemberitaan saham tersebut yang mengalami kemungkinan yang menyebabkan underpricing. Penelitian ini menggunakan periode pengamatan tahun 2016-2018. Berdasarkan uraian di atas rumusan masalah penelitian ini yaitu bagaimanakah Pengaruh Informasi Akuntansi dan Permintaan Investor terhadap Underpricing.

Teori Sinyal digunakan untuk memberikan penjelasan bahwa pada dasarnya suatu informasi yang dimanfaatkan perusahaan untuk memberi sinyal positif maupun negatif kepada pemakainya (Ratnasari \& Hudiwinarsih, 2013). Teori sinyal dalam underpricing emisi perdana merupakan mekanisme yang digunakan oleh perusahaan untuk mengetahui kondisi perusahaan untuk membedakan perusahaan yang baik dengan perusahaan yang kurang baik. Pihak perusahaan sebagian besar memiliki informasi mengenai prospek perusahaannya masing-masing (Grinbaltt \& Hwang, 1989). Ferrer (2016) 
mengatakan bahwa apabila perusahaan memberikan sinyal berupa kabar buruk, maka akan berdampak pada penurunan harga saham. Teori ini menjelaskan dimana perusahaan yang berkinerja baik akan memberikan sinyal mengenai kualitas dan prospek dimasa depan untuk meyakinkan calon investor sehingga dapat meningkatkan permintaan investor (Widarjo \& Bandi, 2018). Perusahaan dapat mengurangi tingkat ketidakpastian pada investor dengan adanya peningkatan informasi untuk memberikan sinyal positif kepada investor dengan menggambarkan kualitas dari perusahaan tersebut (Heerden \& Alagidede, 2012).

Initial Public Offering (IPO) biasa disebut juga sebagai penjualan saham di pasar perdana. Pertama kalinya pada definisi IPO memunculkan adanya pasar perdana yang memiliki definisi sebagai pasar dimana perusahaan publik menawarkan saham kepada calon investor untuk pertama kalinya, selanjutnya transaksi yang dilakukan di bursa disebut pasar sekunder (Ang, 2007). Apabila permintaan lebih besar daripada penawaran maka harga saham akan naik, begitu juga sebaliknya apabila penawaran yang lebih besar daripada permintaan maka harga saham akan menurun. Pada saat masa penawaran suatu perusahaan mengalami kelebihan pemesanan maka dikatakan oversubscribed. Kondisi dimana total saham yang ditawarkan lebih rendah dari total saham yang dipesan oleh investor tersebut yang dinamakan oversubscribed. Kondisi seperti itu yang menyebabkan semua investor kemungkinan mendapatkan saham kurang dari jumlah yang dipesan atau bahkan bisa saja tidak mendapatkan saham sama sekali. Adanya oversubscribed akan berpengaruh terhadap underpricing.

Underpricing terjadi ketika harga penawaran IPO lebih rendah dari harga penutupan setelah hari pertama perdagangan (Bozzolan \& Ipino, 2007). Harga saham dipasar sekunder merupakan referensi penting untuk penetapan harga IPO dan juga merupakan kriteria utama untuk keberhasilan IPO (Zhou \& Lao, 2012). Beberapa literature menjelaskan bahwa informasi asimetri yang menyebabkan terjadinya underpricing. Asimetri informasi biasanya terjadi antara emiten, penjamin emisi, dan antar investor (Azevedo et al., 2018). Asimetri informasi adalah salah satu penyebab terjadinya underpricing. Model Baron menemukan adanya asimetri informasi antara pemilik perusahaan dengan underwriter, sedangkan model Rock menemukan adanya asimetri informasi antara investor yang memiliki informasi dan yang tidak memiliki informasi.

Menurut model Baron (1982) Underwriter memiliki informasi yang lebih tentang pasar modal, sedangkan yang tidak memiliki informasi pasar modal adalah emiten. Pada model Rock (1986) asimetri informasi disebabkan adanya beberapa investor yang tidak memiliki informasi dan ada yang memiliki informasi tentang prospek kedepan dari perusahaan emiten. Investor yang tidak memiliki informasi akan mendapatkan kerugian yang lebih banyak karena kelompok ini akan membeli saham secara sembarangan baik saham yang underpricimg ataupun saham yang overpricing sehingga banyak yang meninggalkan pasar, berbeda dengan investor yang memiliki informasi mereka akan membeli saham IPO bila nantinya akan memberikan return. Saham IPO harus cukup underpricing agar semua investor berpartisipasi di pasar perdana dan memungkinkan memperoleh keuntungan yang wajar serta dapat menutup kerugian akibat pembelian saham overpricing. Untuk mengurangi terjadinya informasi asimetri maka perlu melakukan penerbitan prospektus. Informasi yang 
terdapat di prospektus akan membantu investor untuk membuat atau mengambil keputusan yang rasional mengenai risiko nilai saham sesungguhnya yang ditawarkan emiten (Wiyani, 2016).

Prospektus merupakan suatu dokumen disuatu perusahaan yang memberikan informasi tentang perusahaan penerbit sekuritas dan informasi lainnya yang berkaitan dengan sekuritas yang ditawarkan (Hartono, 2017). Dalam prospektus terdapat seluruh informasi yang penting dan relevan mengenai penawaran umum investasi yang akan dijual ke publik yang dijelaskan secara rinci sehingga dapat membantu investor dalam mengambil keputusan investasi (Kenessov \& Kanzhigalina, 2018).

Berdasarkan teori sinyal, perusahaan menunjukkan sinyal positif pada investor mengenai tingkat profitabilitas bahwa perusahaannya dimasa mendatang dapat menghasilkan keuntungan. Informasi tingkat keuntungan yang dicapai perusahaan disebut tingkat profitabilitas. Informasi tersebut yang nantinya akan memberikan informasi kepada pihak luar mengenai efektifitas operasional perusahaan. ROA digunakan untuk menilai profitabilitas perusahaan. Apabila profitabilitas suatu perusahaan tinggi maka akan mengurangi ketidakpastian bagi investor untuk membeli saham perusahaan pada saat IPO sehingga mengurangi tingkat underpricing (Mudrik \& Imam, 2002 dalam Razafindrambinina \& Kwan, 2013; Permadi \& Yasa, 2017). Maka diajukan hipotesis sebagai berikut.

$\mathrm{H}_{1}$ : Profitabilitas berpengaruh negatif terhadapi underpricing.

Financial Leverage menunjukkan kemampuan suatu perusahaan dalam membayar utangnya dengan equity yang dimilikinya. Financial Leverage yang diproksikan dengan DER diukur dengan total kewajiban dibagi dengan total ekuitas yang dimiliki perusahaan untuk menggambarkan tingkat risiko dari perusahaan (Risal, 2014). Jika financial leverage yang dimiliki perusahaan tinggi maka risiko perusahaan tinggi pula (Kartika \& Putra, 2017). Berdasarkan teori sinyal, perusahaan yang memiliki Financial Leverage yang tinggi akan memberikan sinyal kepada para investor untuk menghindari saham-saham tersebut. Kemampuan dalam membayar hutang dengan equity yang dimiliki perusahaan ditunjukkan dengan Financial Leverage. Jika perusahaan memiliki financial leverage tinggi, maka akan menunjukkan risiko suatu perusahaan yang tinggi pula (Yasa \& Hartono, 2003; Widhiastina \& Prihatni, 2016). Berdasarkan hal itu disusun hipotesis, yaitu.

$\mathrm{H}_{2}$ : Financial Leverage berpengaruh positif terhadap underpricing.

Ukuran perusahaan adalah nilai yang menentukan besar kecilnya perusahaan yang ditunjukkan dengan total aset yang dimiliki perusahaan (Suryawan, 2015). Total aset merupakan tolak ukur besaran suatu perusahaan. Pengukuran untuk ukuran perusahaan dapat diukur dengan menggunakan total aset dan total penjualan, total aset dianggap lebih baik dari total penjualan karena total aset lebih stabil dan lebih menunjukkan kekayaan perusahaan yang digunakan untuk mencapai tujuan perusahaan daripada total penjualan (Suryawan, 2015). Ukuran perusahaan diukur menggunakan log natural (LN) total aset (Adhiati, 2015). Perusahaan dianggap mampu menunjukkan ukuran perusahaan dengan total aset, baik aset lancar maupun aset tetap karena dapat menunjukkan besarnya aset yang dimiliki perusahaan tersebut (Carter \& 
Manaster, 1990). Berdasarkan teori sinyal, menyatakan perusahaan besar akan memberikan sinyal dengan informasi yang disediakan dalam prospektus contohnya informasi mengenai ukuran perusahaan. Jumlah total aset yang dimiliki perusahaan menunjukkan ukuran perusahaan. Aset perusahaan besar akan menunjukkan sinyal bahwa perusahaan mempunyai prospek. Ukuran perusahaan yang lebih besar tentunya lebih dikenal dibandingkan dengan perusahaan kecil. Perusahaan yang besar akan mudah didapat informasinya sehingga ketidakpastian terhadap nilai perusahaan menjadi berkurang yang akan membuat tingkat underpricing semakin rendah (Maulidya \& Lautania, 2016; Yanti \& Yasa, 2016; Ramadana, 2018). Hipotesis yang disusun adalah sebagai berikut.

$\mathrm{H}_{3}$ : Ukuran perusahaan berpengaruh negatif terhadap underpricing.

Perusahaan yang memiliki sinyal positif tentunya dapat menarik minat investor untuk membeli sahamnya. Dilansir dari pemberitaan online economy okezone.com perusahaan yang akan go public melakukan penawaran perdana di pasar primer. Pada saat penawaran perdana jumlah saham yang ditawarkan sangat terbatas, apabila yang memesan saham lebih banyak dari yang ditawarkan maka akan mengalami kelebihan permintaan. Hal tersebut saat waktu penjatahan dapat menyebabkan investor ada yang mendapatkan saham dan ada juga yang tidak. Saat terjadi oversubcribed maka investor yang belum mendapatkan saham akan melakukan pembelian di pasar sekunder. Harga saham dipasar sekunder tentunya lebih tinggi daripada harga saham di pasar primer, maka hal tersebut yang menyebabkan harga sahamnya menjadi meningkat tajam. Semakin tinggi permintaan investor pada saat IPO maka akan semakin tinggi pula tingkat underpricing. Dengan demikian hipotesis yang diajukan adalah sebagai berikut.

$\mathrm{H}_{4}$ : Permintaan investor berpengaruh terhadap underpricing.

\section{METODE PENELITIAN}

Penelitian ini menggunakan pendekatan kuantitatif dengan jenis asosiatif. Obyek dalam penelitian ini adalah seluruh perusahaan yang mengalami underpricing. Penelitian ini menggunakan seluruh perusahaan yang melakukan IPO pada tahun 2016 sampai tahun 2018 yang terdaftar di Bursa Efek Indonesia (BEI). Jenis data yang digunakan yaitu menggunakan data sekunder yang meliputi informasi prospektus dan informasi permintaan saham pada saat IPO yang diperoleh dari situs internet www.idx.co.id. Variabel terikat dalam penelitian ini adalah underpricing. Variabel bebas dalam penelitian ini adalah profitabilitas, financial leverage, ukuran perusahaan dan permintaan investor.

Underpricing adalah selisih antara harga penutup saham pada saat hari pertama perusahaan melakukan IPO dengan harga saham pada penawaran perdana (Purwanto et al., 2014). Rumus underpricing dapat dihitung menggunakan rumus sebagai berikut.

$\mathrm{UP}=\frac{\underset{\mathrm{p} t 1-\mathrm{pt} 0}{\mathrm{pt} 0}}{\mathrm{~K}} \times 100 \%$

Keterangan:

$\mathrm{UP}=$ underpricing saham perusahaan $\mathrm{i}$

$\mathrm{Pt}_{1} \quad=$ Harga saham penutupan hari pertama 
$\mathrm{Pt}_{0} \quad=$ Harga saham perdana

Profitabilitas adalah rasio yang menunjukan kemampuan perusahaan dalam memperoleh laba atau ukuran efektifitas pengelolaan manajemen perusahaan. Salah satu rasio profitabilitas yang digunakan untuk mengukur efektivitas perusahaan dalam menghasilkan keuntungan atau laba dengan memanfaatkan aktiva yang dimilikinya, yaitu ROA (Yanti \& Yasa, 2016). Nilai ROA dapat diukur dengan rumus sebagai berikut.

Laba Bersih Setelah Pajak

ROA $=$ Total Aset $\times 100 \%$

DER adalah salah satu rasio yang terdapat di leverage. DER merupakan rasio untuk mengukur sejauh mana besar hutang yang ditutupi oleh modal sendiri. Apabila DER semakin besar maka akan menandakan risiko perusahaan yang relative tinggi (Wulandari, 2011). Perhitungan DER dalam penelitian ini diukur dengan rumus sebagai berikut.

DER $=\frac{\text { Total Debt }}{\text { Total equity }}$

Keterangan:

DER = Debt to equity ratio

Total debt $=$ Total utang yang dimiliki perusahaan

Equity = Total modal yang dimiliki perusahaan

Ukuran perusahaan ini diukur dengan meilihat total aset yang dimiliki perusahaan. Kepercayaan investor dapat ditentukan dari ukuran perusahaan karena semakin besar perusahaan tersebut maka semakin dikenal oleh publik sehingga informasi mengenai perusahaan mudah didapatkan. Hal tersebut dapat mengurangi tingkat ketidakpastian yang membuat tingkat underpricing menjadi lebih rendah.

Size $=$ Ln (Total Aset $)$

Permintaan investor merupakan permintaan saham dari perusahaan go public pada saat penawaran perdana. Permintaan investor dapat berpengaruh terhadap underpricing. Semakin banyak permintaan investor daripada penawaran maka perusahaan tersebut akan mengalami oversubscribed. Variabel permintaan investor ini menggunakan variabel dummy. Apabila suatu perusahaan kelebihan permintaan maka diberi nilai 1, sedangkan perusahaan yang tidak memiliki kelebihan permintaan maka diberi nilai 0 .

Populasi dalam penelitian ini adalah seluruh perusahaan yang terdaftar di Bursa Efek Indonesia (BEI) pada tahun 2016-2018, didapat 110 perusahaan yang melakukan IPO. Sampel yang digunakan dalam penelitian ini, yaitu dipilih dengan metode purposive sampling. Kriteria pemilihan sampel pada penelitian ini yaitu Perusahaan yang melaksanakan IPO di BEI pada tahun 2016-2018, Perusahaan yang mengalami underpricing, dan Perusahaan yang tidak memiliki laba negatif.

Teknik analisis data yang digunakan, yaitu analisis deskriptif dan analisis regresi liniear berganda dengan menguji uji asumsi klasik terlebih dahulu (uji normalitas, uji heteroskedastisitas, multikolinearitas, dan autokorelasi) dan selanjutnya dilakukan uji kelayakan model, koefisien determinasi dan uji hipotesis. Analisis ini menggunakan bantuan SPSS, maka akan ditentukan bentuk model persamaan regresi linier berganda sebagai berikut. 
$\mathrm{UP}=\beta_{0}+\beta_{1} \mathrm{ROA}_{\mathrm{i}}+\beta_{2} \mathrm{DER}_{\mathrm{i}}+\beta_{3} \mathrm{SIZE}_{\mathrm{i}}+\beta_{4} \mathrm{OVSD}_{\mathrm{i}}+\varepsilon_{\mathrm{i}}$

Keterangan:

$\mathrm{UP}=$ underpricing saham perusahaan

$\beta_{0} \quad=$ konstanta

$\beta_{1}-\beta_{4} \quad=$ koefisien regresi masing-masing variabel

$\mathrm{ROA}_{\mathrm{i}}=$ return on asset pada perusahaan $\mathrm{i}$

$\mathrm{DER}_{\mathrm{i}}=$ debt to equity ratio pada perusahaan $\mathrm{i}$

$\mathrm{SIZE}_{\mathrm{i}}=$ ukuran perusahaan

$\mathrm{OVSD}_{\mathrm{i}}=$ variabel dummy untuk perbedaan tingkat permintaan investor pada perusahaan i.

$\varepsilon_{\mathrm{i}} \quad=$ error term

\section{HASIL DAN PEMBAHASAN}

Berdasarkan kriteria pemilihan sampel, terdapat perusahaan yang mengalami overpricing sebanyak 9 perusahaan. Perusahaan yang memiliki laba negatif sebanyak 17 perusahaan, sedangkan 3 perusahaan mengalami data outlier sehingga harus dikeluarkan dari sampel. Jumlah sampel yang dapat diambil berjumlah 81 perusahaan.

Analisis statistik deskriptif ini disajikan untuk mengetahui gambaran dari masing-masing variabel yang menunjukan jumlah sampel, nilai minimum, nilai maksimum, nilai rata-rata, dan deviasi standar.

Tabel 1. Hasil Analisis Statistik Deskriptif

\begin{tabular}{llllll}
\hline & N & Minimin & Maksimum & Rata-rata & $\begin{array}{l}\text { Deviasi } \\
\text { Standar }\end{array}$ \\
\hline UP & 81 & 0,45 & 70,00 & 44,78 & 24,51 \\
ROA & 81 & 0,01 & 16,02 & 4,42 & 3,99 \\
DER & 81 & 0,06 & 9,97 & 1,72 & 1,69 \\
SIZE & 81 & 9,51 & 17,55 & 13,34 & 1,47 \\
OVSD & 81 & 0 & 1 & 0,72 & 0,45 \\
\hline
\end{tabular}

Sumber: Data Penelitian, 2019

Variabel underpricing menunjukkan bahwa nlai rata-rata tingkat underpricing sebesar 44,78 persen cenderung mendekati nilai tertinggi yang artinya banyak sampel perusahaan penelitian ini mengalami underpricing yang tinggi. Profitabilitas diproksikan dengan ROA menunjukkan bahwa nilai ratarata ROA sebesar 4,42 persen cenderung mendekati nilai terendah yang artinya sampel perusahaan penelitian ini lebih banyak memiliki ROA yang rendah. Financial Leverage diproksikan dengan DER menunjukkan bahwa nilai rata-rata DER yaitu 1,72 persen cenderung mendekati nilai terendah yang artinya sampel perusahaan pada penelitian ini lebih dominan memiliki DER yang rendah.

Ukuran perusahaan yang di transformasi logaritma natural dari total aset menunjukkan bahwa nilai rata rata ukuran perusahaan sebesar 13,34 cenderung mendekati nilai tertinggi yang artinya sampel perusahaan pada penelitian ini lebih banyak memiliki ukuran perusahaan yang besar. Permintaan investor (oversubcribed) menunjukkan bahwa nilai rata-rata permintaan investor sebesar 0,72 persen cenderung mendekati nilai tertinggi yang artinya sampel perusahaan ini banyak mengalami kelebihan permintaan yang tinggi. Nilai deviasi standar menunjukkan dimana variabel bebas dan variabel terikat pada penelitian ini 
lebih rendah dari rata rata, yang menunjukkan bahwa sebaran data variabel tersebut terdistribusi secara normal.

Uji normalitas merupakan asumsi yang sangat mendasar dalam analisis multivariate (Hair et al., 1998:64). Uji Normalitas menunjukan bahwa nilai signifikansi Asymp. Sig. (2-Tailed) sebesar 0,498 > 0,05 yang artinya dapat disimpulkan bahwa data berdistribusi normal.

Uji autokorelasi menunjukkan bahwa hasil analisis data diketahui nilai DW sebesar 1,857 dengan perbandingan nilai DW tabel sebesar $\mathrm{dl}=1,537 \mathrm{dan} \mathrm{du}$ $=1,743$ sehingga $4-\mathrm{d}_{\mathrm{u}}=4-1,743=2,257$. Berdasarkan hasil data SPSS dapat diketahui bahwa nilai DW berada diantara nilai $\mathrm{d}_{\mathrm{u}}$ dan $4-\mathrm{d}_{\mathrm{u}}(1,743<1,857<$ $2,257)$ maka pada model regresi berarti tidak terjadi gejala autokorelasi.

Uji multikolinearitas digunakan untuk menguji model regresi apakah terdapat kolerasi antar suatu variabel bebas dengan variabel bebas lainnya. Apabila model regresi tidak terdapat korelasi antar variabel independen maka model regresi tersebut baik. Uji multikolinearitas menunjukkan bahwa nilai tolerance $>0,1$ dan VIF $<10$, maka tidak terdapat multikolinearitas pada model regresi.

Uji heteroskedastisitas dalam penelitian ini menggunakan Uji White. Berdasarkan hasil uji penelitian diketahui bahwa $R$ square $\left(R^{2}\right)=0,094$, untuk dapat nilai $\mathrm{c}^{2}$ hitung $=81 \times 0,094=7,614$. Setelah mendapat nilai $\mathrm{c}^{2}$ hitung maka selanjutnya mencari nilai $c^{2}$ tabel dengan Df $=4-1=3$, nilai $\mathrm{c}^{2}$ tabel sebesar 7,815. Nilai $\mathrm{c}^{2}$ hitung $<\mathrm{c}^{2}$ tabel dengan nilai 7,614 $<7,815$, maka dapat dikatakan penelitian ini tidak terjadi gejala heteroskedastisitas.

Tabel 2. Hasil Regresi Linear Berganda

\begin{tabular}{clllll}
\hline Model & \multicolumn{2}{l}{$\begin{array}{l}\text { Unstandardized } \\
\text { Coefficients }\end{array}$} & $\begin{array}{l}\text { Standardized } \\
\text { Coefficients }\end{array}$ & T & Sig. \\
\cline { 2 - 4 } & $\mathrm{B}$ & Std. Error & Beta & & \\
\cline { 1 - 3 } (Constant) & 108,072 & 22,581 & & 4,786 & 0,000 \\
ROA & $-2,336$ & 0,617 & $-0,380$ & $-3,783$ & 0,000 \\
DER & $-2,391$ & 1,464 & $-0,165$ & $-1,634$ & 0,106 \\
SIZE & $-3,575$ & 1,692 & $-0,214$ & $-2,113$ & 0,038 \\
OVSD & $-1,652$ & 5,412 & $-0,031$ & $-0,305$ & 0,761 \\
Adjusted R Square & 0,201 & & & \\
F & 6,026 & & & \\
Sig. & $0,000^{a}$ & & & \\
\hline
\end{tabular}

Sumber: Data Penelitian, 2019

Uji kelayakan model (uji F) menunjukkan nilai p-value (sig.) adalah sebesar 0,000. Nilai p-value (sig.) $0,000 \leq 0,05$, maka menunjukkan bahwa penelitian ini layak digunakan sebagai alat analisis yang digunakan untuk menguji pengaruh variabel bebas pada variabel terikat.

Koefisien determinasi $\left(\mathrm{R}^{2}\right)$ menunjukkan bahwa adjusted $\mathrm{R}^{2}$ sebesar 0,201 yang berarti bahwa 20,1 persen tingkat underpricing dipengaruhi oleh variabel profitabilitas, financial leverage, ukuran perusahaan dan permintaan investor. Sebanyak 79,9 persen tingkat underpricing dipengaruhi oleh faktor selain dalam model penelitian tersebut. 
Tabel 2. menunjukkan bahwa hasil dari pengujian diperoleh nilai statistik t yaitu $-3,783$ dan nilai, signifikansi 0,000 < 0,05. Hal ini menunjukkan hipotesis yang berbunyi profitabilitas berpengaruh negatif terhadap underpricing diterima. Hal ini menunjukkan profitabilitas yang tinggi akan mengurangi ketidakpastian bagi investor sehingga menurunkan tingkat underpricing. Tingginya tingkat profitabilitas maka tingkat underpricing dapat diminimalisir, karena investor yakin menjual harga saham perusahaan dengan harga yang tinggi. Perusahaan yang dapat menghasilkan laba besar, sahamnya akan lebih diminati oleh investor. Semakin besar laba yang dihasilkan, maka alokasi dana untuk investor akan besar. Bagi investor informasi laporan keuangan yang terdapat dalam prospektus akan dapat berguna dalam menanamkan dananya di perusahaan tersebut karena dianggap perusahaan yang akan go public adalah perusahaan pilihan yang mempunyai rasio keuangan yang bagus dan terlebih laporan keuangan perusahaan tersebut telah diaudit. Penelitian ini mendukung penelitain sebelumnya seperti Permadi \& Yasa (2017); Ramadana (2018), yang menemukan profitabilitas berpengaruh negatif terhadap underpricing.

Tabel 2. menunjukkan bahwa hasil pengujian didapat nilai statistik $\mathrm{t}$ sebesar $-1,634$ dengan nilai signifikansi 0,106 >0,05. Hal ini menunjukkan hipotesis yang berbunyi financial leverage berpengaruh positif terhadap underpricing ditolak. Hal ini kemungkinan dapat disebabkan adanya sampel perusahaan industri keuangan yang menyimpan dana pihak ketiga sehingga berbeda dengan sektor lain. Financial leverage yang diproksikan dengan DER menggambarkan tingkat risiko dari perusahaan yang diukur dengan membandingkan total hutang perusahaan dengan total ekuitas yang dimiliki perusahaan. Minat investor dalam berinvestasi pada perusahaan akan berkurang apabila tingkat ketidakpastian suatu perusahaan besar. Underwriter menetapkan harga perdana lebih rendah dari harga sewajarnya karena rendahnya minat investor, hal ini untuk menghindari risiko jika saham tidak terjual semua. Penelitian ini tidak mendukung penelitian sebelumnya seperti Widhiastina \& Prihatni (2016); Permadi \& Yasa (2017), yang menemukan bahwa financial leverage berpengaruh positif terhadap underpricing. Penelitian ini mendukung penelitian sebelumnya seperti (Assari et al., (2014); Lestari \& Sulasmiyati (2017), yang menemukan bahwa financial leverage tidak berpengaruh terhadap underpricing.

Tabel 2. menunjukkan bahwa hasil dari pengujian didapat nilai statistik $t$ sebesar $-2,113$ dan nilai signifikansi 0,038 < 0,05. Hal ini menunjukkan bahwa hipotesis yang berbunyi ukuran, perusahaan, berpengaruh negatif terhadap underpricing diterima. Hal ini menunjukkan bahwa umumnya perusahaan besar lebih, dikenal sehingga informasi mengenai perusahaan tersebut lebih banyak. Perusahaan besar lebih mampu memberikan akses informasi yang lebih kepada masyarakat. Informasi tersebut dapat digunakan para investor untuk menganalisa perusahaan sehingga mengurangi risiko yang akan terjadi dimasa yang akan datang. Hal ini sesuai dengan penelitian Permadi \& Yasa (2017); Ramadana (2018), yang menemukan bahwa ukuran perusahaan berpengaruh negatif terhadap underpricing.

Tabel 2. menunjukkan bahwa hasil pada pengujian diperoleh nilai statistik $t$ sebesar $-0,305$ dan nilai signifikansi 0,761 >0,05. Hal ini menunjukkan hipotesis yang berbunyi permintaan investor berpengaruh terhadap underpricing 
ditolak. Hal ini kemungkinan disebabkan menggunakan variabel dummy kerena variasinya tidak terlalu banyak dan juga adanya pembatasan kenaikan harga saham. Secara rata-rata perusahaan di indonesia banyak yang mengalami underpricing, akan tetapi kenaikan harga saham pada perusahaan akan tetap saja dibatasi walaupun perusahaan tersebut mengalami kelebihan permintaan atau tidak mengalami kelebihan permintaan. Kenaikan harga saham yang dibatasi menyebabkan tidak adanya perbedaan, lain halnya apabila tidak dibatasi kenaikan harga sahamnya kemungkinan bisa signifikan. Harga penawaran jual dan permintaan beli yang dimasukkan ke dalam JATS NEXT-G adalah harga penawaran yang masih di dalam rentang harga tertentu. Apabila anggota bursa memasukkan harga diluar rentang harga tersebut maka secara otomatis akan ditolak oleh JATS NEXT-G (auto rejection). Batasan auto rejection yang berlaku saat ini sesuai peraturan Nomor II-A Kep-00168/BEI/11-2018.

\section{SIMPULAN}

Berdasarkan hasil penelitian dan hasil pembahasan yang telah diuraikan maka dapat ditarik kesimpulan bahwa Variabel profitabilitas berpengaruh negatif terhadap underpricing.Variabel financial leverage tidak berpengaruh terhadap underpricing. Variabel ukuran perusahaan berpengaruh negarif terhadap underpricing. Permintaan investor tidak berpengaruh terhadap underpricing.

Bagi perusahaan yang akan melakukan IPO, sangat perlu bagi perusahaan untuk memperhatikan profitabilitas dan ukuran perusahaan karena memiliki pengaruh terhadap underpricing. Kegiatan IPO dapat mengoptimalkan potensi keuntungan perusahaan dengan menekan tingkat underpricing. Bagi investor saat berinvestasi dapat mempertimbangkan profitabilitas dan ukuran perusahaan dalam memilih saham perusahaan yang melakukan IPO. Peneliti selanjutnya disarankan untuk menambah variabel lainnya yang memengaruhi underpricing seperti, reputasi auditor, reputasi underwriter, dan umur perusahaan. Peneliti juga disarankan untuk melakukan pemisahan sektor industri, sehingga dapat memperoleh hasil yang lebih terperinci dalam menjelaskan fenomena underpricing dan disarankan untuk variabel underpricing tidak menggunakan variabel dummy karena variabel dummy variasinya tidak terlalu banyak.

\section{REFERENSI}

Adhiati, A. H. (2015). Analisis Faktor-Faktor yang Mempengaruhi Tingkat Underpricing Pada Perusahaan yang Melakukan Penawaran Saham Perdana di Bursa Efek Indonesia Periode 2009-2013, Jurnal Ekonomi Fakultas Ekonomi dan Bisnis Universitas Dian Nuswantoro, 1-14.

Ang, R. (2007) Buku Pintar Pasar Modal Indonesia (The Intelligent Guide To Indonesian Capital Market), Mediasoft Indonesia.

Assari, H. N., Juanda, A. dan Suprapti, E. (2014). Pengaruh Financial Leverage, ROI, ROE, Reputasi Auditor, dan Reputasi Underwriter terhadap Tingkat Underpricing Saham pada Saat IPO di BEI, Jurnal Reviu Akuntansi dan Keuangan, 4(1), 545-554.

Azevedo, A., Guney, Y. and Leng, J. (2018). Initial Public Offerings in China: Underpricing, Statistics and Developing Literature, Research in 
International Business and Finance. Elsevier B.V. doi: 10.1016/j.ribaf.2018.04.011.

Baron, D. P. (1982). A Model of the Demand for Investment Banking Advising and Distribution Services for New Issues, The Journal of Finance. doi: 10.1111/j.1540-6261.1982.tb03591.x.

Bozzolan, S. and Ipino, E. (2007). Information Asymmetries and IPO Underpricing: The Role of Voluntary Disclosure of Forward-Looking Information in the Prospectus, SSRN Electronic Journal, 1-36. doi: 10.2139 /ssrn. 999518 .

Brown, S. and Hillegeist, S. A. (2007) How Disclosure Quality Affects The Level of Information Asymmetry, Review of Accounting Studies, 1-53.

Carter, R. and Manaster, S. (1990). Initial Public Offerings and Underwriter Reputation, The Journal of Finance, 45(4), 1045-1067. doi: 10.1111/j.15406261.1990.tb02426.x.

Ferrer, R. c. (2016). The Extent of Their Compliance With Merger and Acquisition Disclosure Requirements: a Test of Ross Signaling Theory. Academy of Accounting \& Financial Studies Journal, 20(2), 74-92. Available at: http://esc-

web.lib.cbs.dk/login?url=http:// search.ebscohost.com/login.aspx?direc $\mathrm{t}=$ true\& $\mathrm{db}=\mathrm{bth} \& A \mathrm{~N}=118436486 \&$ site $=$ ehost-live\&scope $=$ site.

Grinblatt, M. and Hwang, C. Y. (1989). Signalling and the Pricing of New Issues, The Journal of Finance. doi: 10.1111/j.1540-6261.1989.tb05063.x.

Hair, J. F., Andreson, R. E., Tatham, R. L. and Black, W.C. (1998). Multivariate data analysis with readings (5nd ed.), Prentice-Hall, Upper Saddle River.

Hartono, J. (2017) Teori Portofolio dan Analisis Investasi. Edisi 11.

Heerden, G. V. and Alagidede, P. (2012). Short Run Underpricing of Initial Public Offerings (IPOs) in The Johannesburg Stock Exchange (JSE), Review of Development Finance. University of Cairo., 2, 130-138. doi: 10.1016/j.rdf.2012.10.001.

Kartika, G. A. S. K. dan Putra, I. M. P. D. (2017). Faktor - Faktor Underpricing Initial Public Offering di Bursa Efek Indonesia, E-Jurnal Akuntansi Universitas Udayana, 19, 2205-2233.

Kenessov, N. and Kanzhigalina, M. (2018). Sentiment of Prospectus and IPO Underpricing, Norwegian School Of Economics, 1-37.

Kim, J.-B., Krinsky, I. and Lee, J. (1995). The Role of Financial Variables in the Pricing Korean IPO, Pacific Business Finance Journal, 3(4), 393-498.

Lestari, F. A. dan Sulasmiyati, S. (2017). Pengaruh Informasi Keuangan terhadap Underpricing (Studi Pada Perusahaan Yang Melaksanakan IPO Pada Bursa Efek Indonesia Tahun 2012), Jurnal Administrasi Bisnis, 46(2), 1-8.

Maulidya, P. S. dan Lautania, M. F. (2016). Pengaruh Asset Turnover, Current Ratio, Debt To Equity Ratio, dan Ukuran Perusahaan Terhadap Terjadinya Underpricing Saham Pada Perusahaan di Pasar Penawaran Saham Perdana yang Terdaftar di Bursa Efek Indonesia Tahun 20102014, Jurnal Ilmiah Mahasiswa Ekonomi Akuntansi (JIMEKA), 1(1), 171-182.

Mayasari, T., Yusuf dan Yulianto, A. (2018). Pengaruh Return on Equity, Net Profit Margin dan Ukuran Perusahaan Terhadap Underpricing, Jurnal Kajian Akuntansi, 2(1), 41-53. 
Permadi, P. K. A. R. dan Yasa, G. W. (2017). Reputasi Auditor Sebagai Pemoderasi Pengaruh Informasi Keuangan dalam Prospektus Pada Tingkat Underpricing Penawaran Saham Perdana, E-Jurnal Akuntansi, 21, 1963-1992. doi: 10.24843/EJA.2017.v21.i03.p10.

Purwanto., Agustiningsih, S. W., Insani, S. F. dan Wahyono, B. (2014). Fenomena Underpricing Pada Perusahaan yang Go Public di Indonesia, Ekonomi Bisnis dan Kewirausahaan, 3(1), 1-23.

Ramadana, S. W. (2018). Beberapa Faktor yang Mempengaruhi Underpricing Saham Pada Perusahaan Yang Melakukan Initial Public Offering (IPO) Di Bursa Efek Indonesia, Jurnal Riset Inspirasi Manajemen dan Kewirausahaan, 2(2), pp. 102-108. doi: 10.35130/jrimk.v2i2.22.

Ratnasari, A. dan Hudiwinarsih, G. (2013). Analisis Pengaruh Informasi Keuangan, Non Keuangan serta Ekonomi Makro Terhadap Underpricing Pada Perusahaan Ketika IPO, Jurnal Buletin Studi Ekonomi, 18(2), 85-97.

Razafindrambinina, D. and Kwan, T. (2013). The Influence of Underwriter and Auditor Reputations on IPO Under-pricing, European Journal of Business and Management, 5(2), 2222-2839. Available at: http://pakacademicsearch.com/pdf-files/ech/517/199-212 Vol 5, No 2 (2013).pdf.

Risal (2014). Underpricing: Informasi Akuntansi Dan Non Akuntansi Dalam Initial Public Offering (Ipo), Akuntabilitas, 7(1), 42-55. doi: 10.15408/akt.v7i1.2645.

Rock, K. (1986). Why new issues are underpriced, Journal of Financial Economics. doi: 10.1016/0304-405X(86)90054-1.

Suryawan, A. (2015). Analisis Faktor-Faktor Yang Mempengaruhi Tingkat Underpricing Harga Saham Pada Perusahaan Yang Melakukan IPO di Bursa Efek Indonesia Periode 201-2014, Fakultas Ekonomi Bisnis UIN Syarif Hidayatullah Jakarta. Available at: http://repository.ubaya.ac.id/id/eprint/25134.

Utamaningsih, A., Tandelilin, E., Husnan, S. and Sartono, R. A. (2013). Asymmetric Information in the Ipo Underwriting Process on the Indonesia Stock Exchange: Pricing, Initial Allocation, Underpricing, and Price Stabilization, Jurnal of Indonesian Economy and Business, 28(3), 311321. doi: 10.22146/jieb.6220.

Widarjo, W. and Bandi (2018). Determinants of Intellectual Capital Disclosure in The IPOs and its Impact on Underpricing: Evidence From Indonesia, International Journal of Learning and Intellectual Capital, 15(1), 1-19. doi: 10.1504/ijlic.2018.088346.

Widhiastina, P. dan Prihatni, R. (2016). Pengaruh Return On Asset, Financial Leverage, dan Ukuran Perusahaan Terhadap Underpricing Pada Perusahaan yang Melakukan Initial Public Offering (IPO) di Bursa Efek Indonesia, Jurnal Ilmiah Wahana Akuntansi, 11, No.2, 1-21.

Wiyani, N. T. (2016). Underpricing Pada Initial Public Offering ( Studi Empiris Pada Perusahaan Non Keuangan yang Go Public di Bursa Efek Indonesia Tahun 2011-2014 ), Jurnal Online Insan Akuntan, 1(2), 341-358. 
Wulandari, A. (2011). Analisis Faktor-Faktor yang Mempengaruhi Tingkat Underpricing Pada Penawaran Perdana ( Studi Kasus Pada Perusahaan Go Publik Yang Terdaftar di Bursa Efek Indonesia Tahun 2006-2010), Jurnal Akuntansi dan Auditing UNDIP, 1.

Yanti, E. dan Yasa, G. W. (2016). Determinan Underpricing Saham Perusahaan Go Public Tahun 2009-2013, E-Jurnal Akuntansi Universitas Udayana, 16.1, 244-274.

Yasa, G. W. dan Hartono, J. (2003). Faktor-Faktor yang Mempengaruhi Underpricing Saham di Bursa Efek Jakarta Tahun 1990-2001, Diss. Universitas Gadjah Mada.

Zhou, J. and Lao, L.-J. (2012). Analysis of Influencing Factors of IPO Underpricing in ChiNext, Physics Procedia, 33, 846-851. doi: 10.1016/j.phpro.2012.05.144. 